\title{
Palladium/Heteropoly Acid Catalyzed Oxidative Coupling of 2-Methoxy-1,4-benzoquinone with Arenes
}

\author{
Rosilene A. de Oliveira ${ }^{a}$, Elena V. Gusevskaya ${ }^{b}$ and Fernando Carazza ${ }^{b *}$ \\ ${ }^{a}$ Departamento de Ciências Exatas e Tecnológicas, DCET, Universidade Estadual de Santa Cruz, 45650-000, \\ Ilhéus - BA, Brazil \\ ${ }^{b}$ Departamento de Química, ICEx, Universidade Federal de Minas Gerais, 32120-901, Belo Horizonte - MG, Brazil
}

O acoplamento oxidativo entre a 2-metoxi-1,4-benzoquinona e metoxiarenos em ácido acético resulta na formação de metoxiaril-1,4-benzoquinonas. Esta reação é efetivamente catalisada pelo sistema redox $\mathrm{Pd}(\mathrm{OAc})_{2}$ /heteropoliácido $\left(\mathrm{H}_{9} \mathrm{PMo}_{6} \mathrm{~V}_{6} \mathrm{O}_{40}\right)$ e envolve dioxigênio como oxidante final.

Oxidative coupling of 2-methoxy-1,4-benzoquinone and arenes in acetic acid gives methoxyaryl-substituted 1,4-benzoquinones. The reaction is effectively catalyzed by a $\mathrm{Pd}(\mathrm{OAc})_{2} /$ heteropoly acid $\left(\mathrm{H}_{9} \mathrm{PMo}_{6} \mathrm{~V}_{6} \mathrm{O}_{40}\right)$ redox system with dioxygen as the final oxidant.

Keywords: oxidative coupling, arenes, quinones, catalysis, palladium/heteropoly acid

\section{Introduction}

Naturally occurring compounds containing a quinone group are involved in various bioenergetic processes as important electron-transport agents. These compounds have also attracted considerable attention because of their biological activity and chemotherapeutic value. ${ }^{1}$ Various quinones containing oxygenated aromatic rings have been reported to present biological activities. ${ }^{2}$ Accordingly, in order to discover new medicinal materials, it is important to develop simple but powerful methods for the synthesis of such compounds, in particular, methoxyaryl-substituted benzoquinones.

Most of the synthetic routes to substituted quinones are based on the elaboration of the preexisting aromatic or heteroaromatic core. The methods for the preparation of aryl-1,4-benzoquinones were limited mainly to the reactions of 1,4-benzoquinones with aryldiazonium salts. ${ }^{3}$ The direct synthesis of aryl-1,4-benzoquinones by oxidative coupling of 1,4-benzoquinone with arenes, such as benzene, 2,5-dimethylbenzene and 2,5-dichlorobenzene, in acetic acid under reflux with stoichiometric amounts of palladium acetate was described by Itahara. ${ }^{4}$ Recently, we have extended this non-catalytic methodology to the

\footnotetext{
* e-mail: carazza@dedalus.lcc.ufmg.br
}

preparation of various methoxyaryl-1,4-benzoquinone, using wood tar constituents as a starting material. ${ }^{5}$

Palladium assisted oxidative reactions may be converted into catalytic processes by the introduction of suitable reoxidants to recycle reduced palladium species. Itahara ${ }^{6}$ reported the palladium catalyzed oxidative coupling of 1,4naphtoquinone with benzene and 2,5-dimethylbenzene using stoichiometric amounts of reoxidants such as peroxodisulfates, $\mathrm{FeCl}_{3}, \mathrm{KMnO}_{4}, \mathrm{~K}_{2} \mathrm{Cr}_{2} \mathrm{O}_{7}$ and $\mathrm{Cu}(\mathrm{OAc})_{2}$. However, he failed to realize, under similar conditions, the oxidative coupling of 1,4-benzoquinone with arenes other than benzene. ${ }^{6}$ We tried to apply the methods described by Itahara to prepare methoxyaryl-1,4-benzoquinones. However, we obtained a complex mixture of unidentified compounds and starting material, with not even trace amounts of quinone-benzene coupling products (2methoxy-1,4-benzoquinone: $1 \mathrm{mmol}, \mathrm{Pd}(\mathrm{OAc})_{2}: 0.05$ mmol, reoxidant $\mathrm{Na}_{2} \mathrm{~S}_{2} \mathrm{O}_{8}$ or $\mathrm{FeCl}_{3}: 1 \mathrm{mmol}$, benzene: 25 $\mathrm{mL}$, acetic acid: $25 \mathrm{~mL}$, reflux temperature, $25 \mathrm{~h}$, in air).

Efforts are being made to develop a catalytic method for the synthesis of methoxyaryl-substituted 1,4-benzoquinones via oxidative coupling of 2-methoxy-1,4-benzoquinone and methoxyarenes using dioxygen as a final oxidant. We now wish to report the oxidative coupling of 2-methoxy-1,4benzoquinone and methoxyarenes by dioxygen in the presence of palladium/heteropoly acid catalytic system (Scheme 1). Keggin-type mixed-addenda heteropoly acids 
$\mathrm{H}_{3+\mathrm{n}}\left[\mathrm{PMo}_{12-\mathrm{n}} \mathrm{V}_{\mathrm{n}} \mathrm{O}_{40}\right](\mathrm{HPA}-\mathrm{n})$ are strong oxidants soluble in water and oxygenated organic solvents, which act reversibly under mild conditions, i.e., their reduced forms are easily recycled by dioxygen. These remarkable compounds are valuable reoxidants for the $\mathrm{Pd}(0) / \mathrm{Pd}(\mathrm{II})$ redox couple in aerobic liquid-phase oxidation processes, such as olefin oxidations and oxidative coupling of arenes. ${ }^{7-10}$

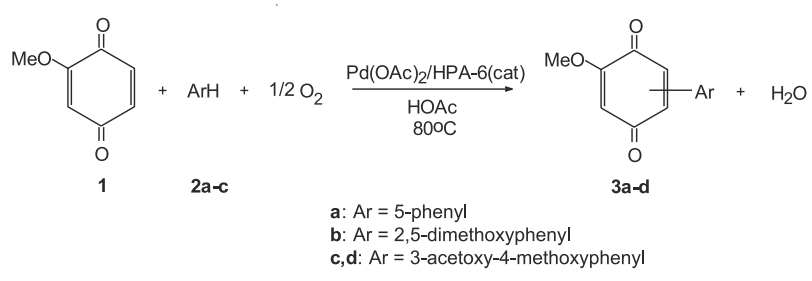

\section{Experimental}

The uncorrected melting points were determined on a Mettler FP800 apparatus. Column chromatography was performed with flash-grade silica gel E. Merck 230-400 mesh. IR spectra were obtained on a PerkinShimadzu IR-408 instrument. ${ }^{1} \mathrm{H}$ and ${ }^{13} \mathrm{C}$ NMR spectra were recorded on an Avance-Bruker DRX-200 or Avance-Bruker DRX-400 instrument $\left(\mathrm{CDCl}_{3}\right.$, tetramethylsilane). The assignment of hydrogen and carbon resonances was realized with the help of COSY $\left({ }^{1} \mathrm{H},{ }^{1} \mathrm{H}\right)$, HMQC $\left({ }^{1} \mathrm{H},{ }^{13} \mathrm{C}\right)$, DEPT NMR and NOESY experiments. Mass spectra were obtained on a Hewlett-Packard MSD 5890/Series II instrument operating at $70 \mathrm{eV}$.

\section{Reagents and materials}

The heteropoly acid $\mathrm{H}_{9}\left[\mathrm{PMo}_{6} \mathrm{~V}_{6} \mathrm{O}_{40}\right]$ (HPA-6) was synthesized by the reaction of $\mathrm{Na}_{2} \mathrm{MoO}_{4}, \mathrm{NaVO}_{3}$ and $\mathrm{H}_{3} \mathrm{PO}_{4}$ in aqueous sulfuric acid solution according to the literature. ${ }^{11}$ 1-Acetoxy-2-methoxybenzene was prepared by the reaction of 2-methoxyphenol with acetyl anhydride and pyridine. ${ }^{12}$ 2-Methoxy-1,4-benzoquinone was prepared by the oxidation of freshly distilled 2-methoxyphenol according to the method of Teuber. ${ }^{13}$

\section{General procedure}

The reactions were carried out in a stirred glass reactor connected to a gas burette and followed by measuring a dioxygen uptake. In a typical run the mixture of 2-methoxy1,4-benzoquinone (1 mmol), arene (1.2 mmol), $\mathrm{Pd}(\mathrm{OAc})_{2}$ (0.05 mmol), HPA-6 (0.25 mmol) and acetic acid $(15 \mathrm{~mL})$ in a dioxygen atmosphere (1MPa) was magnetically stirred at the indicated temperature until the dioxygen uptake decreased significantly. After cooling to room temperature, the reaction solution was filtered and poured into a saturated aqueous solution of $\mathrm{NaCl}$. The products were extracted with chloroform $(3 \times 50 \mathrm{~mL})$, dried over anhydrous $\mathrm{Na}_{2} \mathrm{SO}_{4}$, and the solvent was evaporated in vacuum. The residue (crude product) was analyzed by ${ }^{1} \mathrm{H}$ NMR spectroscopy. The substrate conversion, product distribution and yield were determined based on the integration of the signals from the corresponding olefinic protons (i.e. from the unconverted quinone and from the products). The products were isolated by flash chromatography (silica, hexane/ chloroform) as pure compounds $\mathbf{3 a}$ and $\mathbf{3 b}$ and the isomeric mixture of 3c and 3d (3c/3d @ 60/40) and identified by IR, ${ }^{1} \mathrm{H}$ and ${ }^{13} \mathrm{C}$ NMR spectroscopy.

2-Methoxy-5-phenyl-1,4-benzoquinone (3a): crystalline orange solid, m.p. $187.6-188.9^{\circ} \mathrm{C}\left(\mathrm{Lit}^{14}: 187^{\circ} \mathrm{C}\right)$; IR (KBr) $v_{\max } / \mathrm{cm}^{-1}: 1670,1640,1620,1580,1440 ;{ }^{1} \mathrm{H}$ NMR $(400 \mathrm{MHz}) \delta: 3.87\left(\mathrm{~s}, 3 \mathrm{H}, \mathrm{OCH}_{3}\right), 6.04(\mathrm{~s}, 1 \mathrm{H}, \mathrm{CH}=\mathrm{C})$, 6.81 (s, $1 \mathrm{H}, \mathrm{CH}=\mathrm{C}), 7.4-7.5$ (m, 5H, Ar- $H) ;{ }^{13} \mathrm{C} \mathrm{NMR}(100$ MHz) $\delta: 56.38,108.05,128.51,129.56,130.24,130.92$, 134.30, 146.54, 158.67, 182.21, 186.67; MS m/z (rel.int.): $214\left(\mathrm{M}^{+}, 100\right), 213$ (60), 186 (55), 171 (35), 155 (13), 128 (20), 102 (25), 84 (9), 69 (60); Anal. Calcd. for $\mathrm{C}_{13} \mathrm{H}_{10} \mathrm{O}_{3}$ : C, 72.89; H, 4.70; found C, 72.87; H, 4.67.

2-(2', 5'-Dimethoxyphenyl)-5-methoxy-1,4benzoquinone (3b): crystalline red solid, m.p.: 130.3$131.4^{\circ} \mathrm{C}\left(\mathrm{Lit}^{15} 132-134^{\circ} \mathrm{C}\right)$; IR (KBr) $v_{\max } / \mathrm{cm}^{-1}: 1680,1650$, 1600, 1550, 1460; ${ }^{1} \mathrm{H}$ NMR (200 MHz) $\delta: 3.73$ (s, 3H, $\left.\mathrm{OCH}_{3}\right), 3.74\left(\mathrm{~s}, 3 \mathrm{H}, \mathrm{OCH}_{3}\right), 3.86\left(\mathrm{~s}, 3 \mathrm{H}, \mathrm{OCH}_{3}\right), 6.03$ (s, $1 \mathrm{H}, \mathrm{CH}=\mathrm{C}$ ), $6.72(\mathrm{dd}, J 2.7$ and $0.5 \mathrm{~Hz}, 1 \mathrm{H}, \mathrm{Ar}-H), 6.76$ (s, $1 \mathrm{H}, \mathrm{CH}=\mathrm{C}), 6.90-6.95$ (m, 2H, Ar- $H) ;{ }^{13} \mathrm{C}$ NMR (50 MHz) $\delta: 55.83,56.2,56.37,108.03,112.58,116.02,116.35$, $123.25,132.62,146.25,151.50,153.30,158.50,182.30$, 186.80; MS m/z (rel.int.): $274\left(\mathrm{M}^{+}, 100\right), 259$ (22), 243 (65), 231 (28), 215 (33), 201 (12), 203 (10), 175 (87), 147 (27), 119 (15); Anal. Calcd. for $\mathrm{C}_{15} \mathrm{H}_{14} \mathrm{O}_{5}$ : C, 65.69; H, 5.14; found: C, 65.65; H, 5.12.

2-(3'-Acetoxy-4'-methoxyphenyl)-6-methoxy-1,4benzoquinone (3c) and 2-(3'-acetoxy-4'-methoxyphenyl) -5-methoxy-1,4-benzoquinone (3d): (orange oil) IR (film) $v_{\max } / \mathrm{cm}^{-1}: 3000,1780,1670,1640,1580,1500,1480,1450$, 1350, 1200, 1000; ${ }^{1} \mathrm{H}$ NMR (400 MHz): $\delta 2.36$ (s, 6H, 2 x $\left.\mathrm{COCH}_{3}\right), 3.85\left(\mathrm{~s}, 3 \mathrm{H}, \mathrm{OCH}_{3}\right), 3.86\left(\mathrm{~s}, 3 \mathrm{H}, \mathrm{OCH}_{3}\right), 3.88$ (s, $\left.6 \mathrm{H}, 2 \times \mathrm{OCH}_{3}\right), 5.96(\mathrm{~d}, J 2.3 \mathrm{~Hz}, 1 \mathrm{H}, \mathrm{CH}=\mathrm{C}), 6.00(\mathrm{~s}, 1 \mathrm{H}$, $\mathrm{CH}=\mathrm{C}), 6.75$ (d, J2.3 Hz, 1H, CH=C), 6.79 (s, 1H, CH=C), 7.02 (d, J 8.6 Hz, 2H, 2 x Ar-H), 7.29 (d, J $2.3 \mathrm{~Hz}, 2 \mathrm{H}, 2$ x Ar- $H$ ), 7.40-7.50 (m, 2H, Ar- $H) ;{ }^{13} \mathrm{C}$ NMR (100 MHz) $\delta$ : 20.63, 56.05, 56.35, 56.49, 107.23, 112.22, 112.26, 123.84, $124.39,124.92,125.24,128.16,128.63,129.74,132.30$, 
139.68, 142.66, 144.77, 152.84, 153.06, 158.76, 168.71, 181.14, 182.05, 187.09, 187.11; MS m/z (rel.int.): $302\left(\mathrm{M}^{+}\right.$, 22), 260 (100), 245 (6), 229 (75), 217 (9), 201 (7), 189 (5), 173 (3), 161 (9), 133 (5).

\section{Results and Discussion}

All arenes studied rapidly reacted with 2-methoxy-1,4benzoquinone and dioxygen under the conditions used resulting in the formation of corresponding methoxyarylsubstituted 1,4-benzoquinones (Table 1). Within 4 hours ca. $80 \%$ quinone conversions are achieved with $70-75 \%$ selectivity for the specific coupling product. Dioxygen uptake corresponds to the amounts of quinone reacted and in all the runs presented in Table 1 , their molar ratio is close to stoichiometric one $\left(\mathrm{O}_{2}\right.$ /quinone $\left.=1 / 2\right)$. After this, the gas uptake decreases markedly indicating that the rate of arenearene homocoupling, if any, is rather low. No products of the oxidative arene-arene coupling have been detected in significant amounts. The main advantage of the developed method compared to the previously reported one ${ }^{5}$ is the use of palladium acetate in catalytic amounts. The reoxidant, i.e., heteropoly acid, is also used in catalytic amounts and only dioxygen is consumed as the final oxidant. In addition, lower temperatures $\left(80^{\circ} \mathrm{C}\right.$ vs. reflux temperature) and shorter reaction times ( $4 \mathrm{~h}$ vs. 18-36 $\mathrm{h}$ ) can be used, along with the possibility to monitor the substrate conversion during the reaction by measuring the dioxygen uptake.

Table 1. Palladium/HPA-6 catalyzed oxidative coupling of 2-methoxy-1,4-benzoquinone with arenes by dioxygen. ${ }^{\mathrm{a}}$

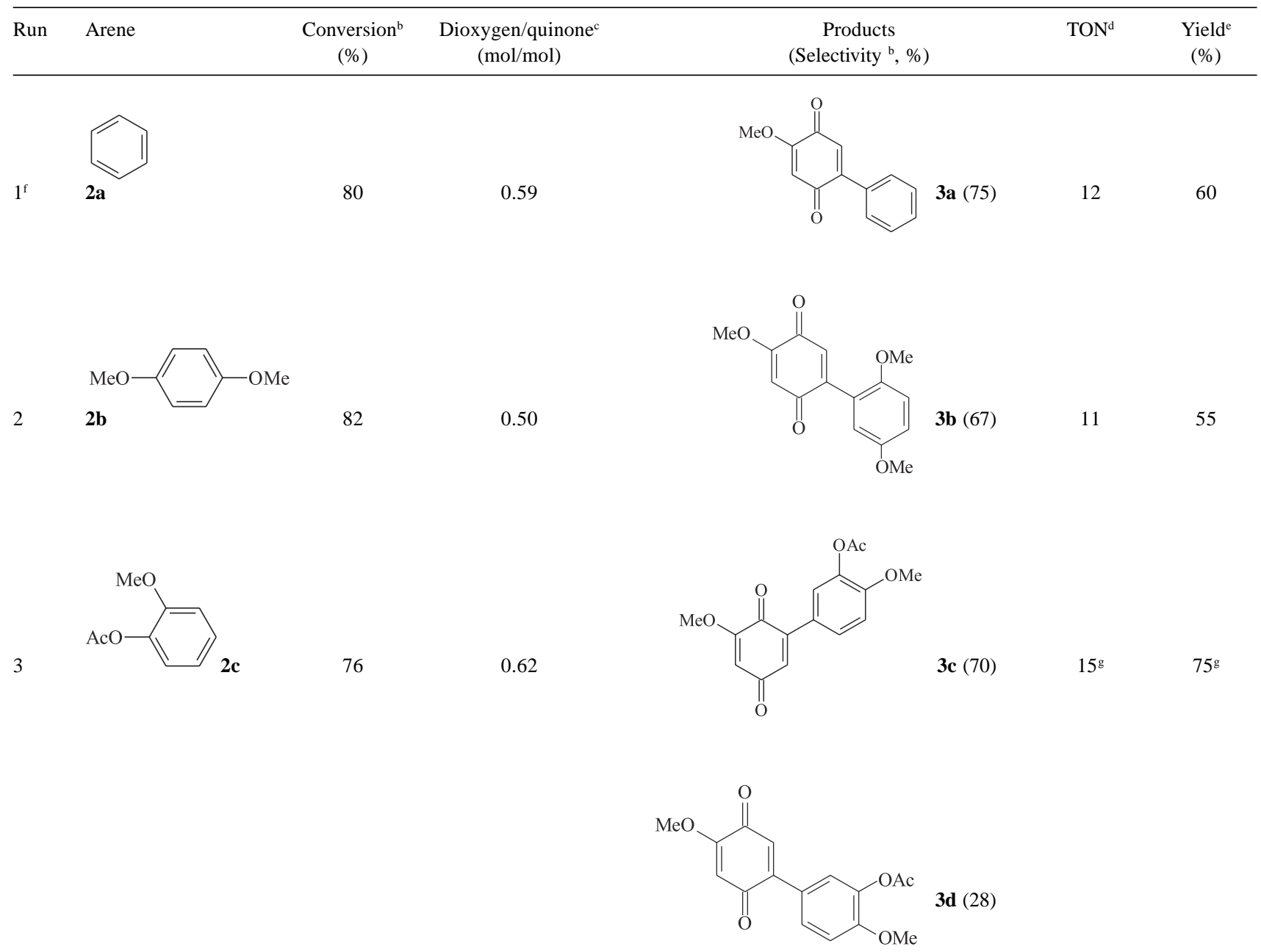

${ }^{a}$ All reactions were performed under the following conditions, unless otherwise indicated: 2-methoxy-1,4-benzoquinone (1 mmol), arene (1.2 mmol), $\mathrm{Pd}(\mathrm{OAc})_{2}(0.05 \mathrm{mmol}), \mathrm{HPA}-6(0.25 \mathrm{mmol}), \mathrm{HOAc}(15 \mathrm{~mL}), \mathrm{O}_{2}(1 \mathrm{MPa}), 80^{\circ} \mathrm{C}, 4 \mathrm{~h} .{ }^{\mathrm{b}}$ Determined by ${ }^{1} \mathrm{HNMR}$ analysis of the crude product. ${ }^{\mathrm{c}} \mathrm{Molar}$ ratio between consumed dioxygen and reacted quinone. ${ }^{\mathrm{d}}$ Turnover numbers. ${ }^{\mathrm{e}}{ }^{1} \mathrm{H}$ NMR yield based on reacted quinone. ${ }^{\mathrm{f}} 25 \mathrm{~mL}$ of benzene. ${ }^{\mathrm{g}}$ For the mixture 3c/3d 
The substituents of the arene strongly influence the regioseletivity of quinone-arene oxidative coupling. In all cases coupling occurs at the $\mathrm{C}-5$ or $\mathrm{C}-6$ positions of quinone (meta or para position with respect to the methoxy group), possibly due to the steric hindrance of the quinone methoxy group. Benzene and 1,4-dimethoxybenzene give mainly 5 -arene-substituted quinone (75 and $67 \%$, respectively; Table 1, runs 1 and 2), while 1-acetoxy-2-methoxybenzene results in 6-arene-substituted quinone (70\%, run 3$)$. Oxidative coupling of 2-methoxy-1,4-benzoquinone with asymmetrically substituted arene, i.e, 1-acetoxy-2methoxybenzene, occurs at the para position with respect to the arene methoxy group (products $\mathbf{3 c}$ and $\mathbf{3 d}$ ).

The results presented in Table 1 have been obtained at the temperature of $80{ }^{\circ} \mathrm{C}$, which has been found to be optimum. The temperature effect on the quinone conversion and product yield at the oxidative coupling of 2-methoxy1,4-benzoquinone and benzene is illustrated by the data summarized in Table 2. The selectivity for the formation of coupling product $\mathbf{3 a}$ and quinone conversion decreases markedly with lowering the reaction temperature. Conversions of 41 and $29 \%$ are observed for $4 \mathrm{~h}$ at 65 and $45^{\circ} \mathrm{C}$, respectively (Table 2 , runs 3 and 4 ), while $80 \%$ at $80^{\circ} \mathrm{C}$ (Table 2, run 2). In addition to the expected reaction deceleration, both the selectivity for $\mathbf{3 a}$, and, consequently, the yield based on quinone drop dramatically (yield of 60\% at $80{ }^{\circ} \mathrm{C}$ vs. $7 \%$ at $45{ }^{\circ} \mathrm{C}$ ). Interestingly, at reflux temperature (ca. $120{ }^{\circ} \mathrm{C}$ ), quinone is consumed at a much lower rate and a dark oil is obtained as a crude product, with only trace amounts of product 3a being detected after $4 \mathrm{~h}$ of reaction. Thus, the degradation of the catalytic system seems to take place at high temperatures.

Table 2. The effect of temperature on the palladium/HPA- 6 catalyzed oxidative coupling of 2-methoxy-1,4-benzoquinone (2a) with benzene resulting in 5-phenyl-2-methoxy-1,4-benzoquinone (3a) ${ }^{\text {a }}$

\begin{tabular}{lccccc}
\hline Run & $\begin{array}{c}\text { Temperature } \\
\left({ }^{\circ} \mathrm{C}\right)\end{array}$ & $\begin{array}{c}\text { Conversion } \\
(\%)\end{array}$ & $\begin{array}{c}\text { Selectivity } \\
\text { for 3a }(\%)\end{array}$ & TON $^{\mathrm{c}}$ & $\begin{array}{c}\text { Yield }^{\mathrm{d}} \\
(\%)\end{array}$ \\
\hline 1 & reflux & 25 & 15 & 0.8 & 4 \\
2 & 80 & 80 & 75 & 12 & 60 \\
3 & 65 & 41 & 43 & 3.6 & 18 \\
4 & 45 & 29 & 25 & 1.4 & 7 \\
\hline
\end{tabular}

a All reactions were performed under the following conditions: 2methoxy-1,4-benzoquinone ( $1 \mathrm{mmol}), \mathrm{Pd}(\mathrm{OAc})_{2}(0.05 \mathrm{mmol})$, HPA- 6 $(0.25 \mathrm{mmol})$, benzene $(25 \mathrm{~mL}), \mathrm{HOAc}(15 \mathrm{~mL}), \mathrm{O}_{2}(1 \mathrm{MPa}), 4 \mathrm{~h} .{ }^{\mathrm{b}}$ Determined by ${ }^{1} \mathrm{H}$ NMR analysis of the crude product. ${ }^{\mathrm{c}}$ Turnover numbers. ${ }^{\mathrm{d}}$ ${ }^{1} \mathrm{H}$ NMR yield based on reacted quinone.

As mentioned above, in the oxidative coupling of 2methoxy-1,4-benzoquinone with arenes at $80^{\circ} \mathrm{C}$, dioxygen is consumed in stoichiometric amounts based on the reacted quinone. Therefore, under these conditions, the effective reoxidation of both the reduced palladium species and the blue-colored reduced forms of HPA-6 ("blue") occurs in solution, which remains brown-colored during the reaction. The catalytic cycle of the oxidative quinone-arene coupling catalyzed by the two-component $\mathrm{Pd}(\mathrm{OAc})_{2} / \mathrm{HPA}-6$ system is presented in Scheme 2. Palladium can be recycled either by HPA-6, as shown in Scheme 2, or, alternatively, by quinone itself, with the hydroquinone formed being reoxidized by HPA-6. Dioxygen oxidizes the HPA- 6 blue $\left[\mathrm{H}_{2}(\mathrm{HPA}-6)\right]$, thus acting as the final oxidant. For all arenes studied the turnover numbers of 11-15 have been achieved (Table 1). It is worthwhile noting that the direct reaction of dioxygen with both $\mathrm{Pd}$ metal and hydroquinones is kinetically unfavorable. ${ }^{16}$

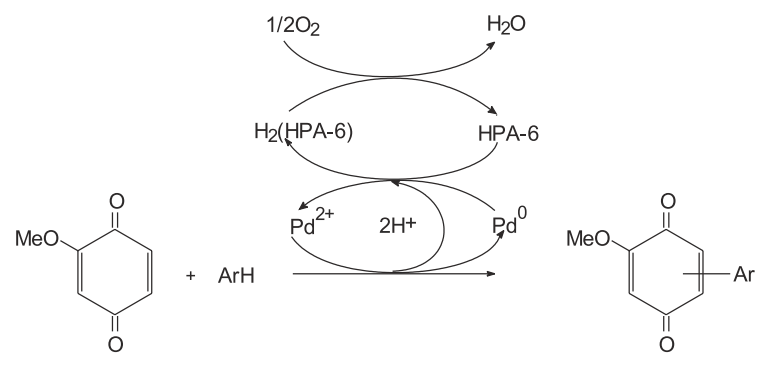

\section{Conclusions}

A novel catalytic method for the synthesis of methoxyaryl-substituted 1,4-benzoquinones via palladium/ heteropoly acid catalyzed oxidative coupling of 2-methoxy1,4-benzoquinone and arenes using dioxygen, which is the most abundant and cheapest oxidant, has been developed. We are presently developing the process showing higher turnover numbers and trying to extend the scope of this highly convenient method.

\section{Acknowledgments}

We gratefully acknowledge the financial support from the $\mathrm{CNPq}$ (Conselho Nacional de Desenvolvimento Científico e Tecnológico) and FAPEMIG (Fundação de Amparo à Pesquisa do Estado de Minas Gerais).

\section{References}

1. Thomson, R.H. In Naturally Occurring Quinones; Chapman and Hall; London, Vol. III, 1987.

2. Dalton, R.D. In The Alkaloids; Academic Press: New York, 1979, p. 264.

3. Patai, S. In The Chemistry of the Quinonoid Compounds; Finley, K.T., Ed.; Wiley; London, 1974; Part 2, p. 1043.

4. Itahara, T.; J. Chem. Soc., Chem. Commun. 1981, 859. 
5. Oliveira, R.A.; Carazza, F.; Pereira, M.O. da S.; Synth. Commun. 2000, 30, 4563.

6. Itahara, T.; J. Org. Chem. 1985, 50, 5546.

7. Rachkovskaya, L. N.; Gusevskaya, E. V.; Matveev, K. I.; Il'inich, G. N.; Eremenko, N. K.; Kinet.Katal. 1977, 18, 792

8. Kozhevnikov, I.V.; Matveev, K.I.; Appl. Catal. 1983, 5, 135.

9. Kozhevnikov, I.V.; Chem. Rev. 1998, 98, 171.

10. Cavani, F.; Catal. Today 1998, 41, 73.

11. Davison, S. F.; Mann, B.E.; Maitlis, P.M.; J. Chem. Soc., Dalton Trans. 1984, 1223.

12. Icke, R.N.; Redemann, C.E.; Wisegarver, B.B.; Alles, G.A.; Org. Synth. 1949, 29, 63.
13. Zimmer, H.; Lankin, D.C.; Horgan, S.W.; Chem. Rev. 1971, $71,229$.

14. Blatchly, J.M.; Green, J.S.R.; McOmie, F.W.J.; Saleh, S.A.; Chem. Soc. Perkin I, 1975, 309.

15. Higuchi, T.; Satake, C.; Hirobe, M.; J. Am. Chem. Soc. 1995, $117,8879$.

16. Heumann, A.; Lens, K.-J.; Réglier, M. In Progress in Inorganic Chemistry; Karlin, K.D., Ed.; Wiley, New York, 1994; Vol. 42, p. 483.

Received: January 3, 2001

Published on the web: November 23, 2001 